\title{
Tritium in Surface Soils at the Mixed Waste Landfill, Technical Area 3, Sandia National Laboratories, New Mexico
}

Jerry L. Peace, Tim J. Goering, Michael D. McVey

Prepared by

Sandia National Laboratories

Albuquerque, New Mexico 87185 and Livermore, California 94550 for the United States Department of Energy under Contract DE-AC04-94AL85000

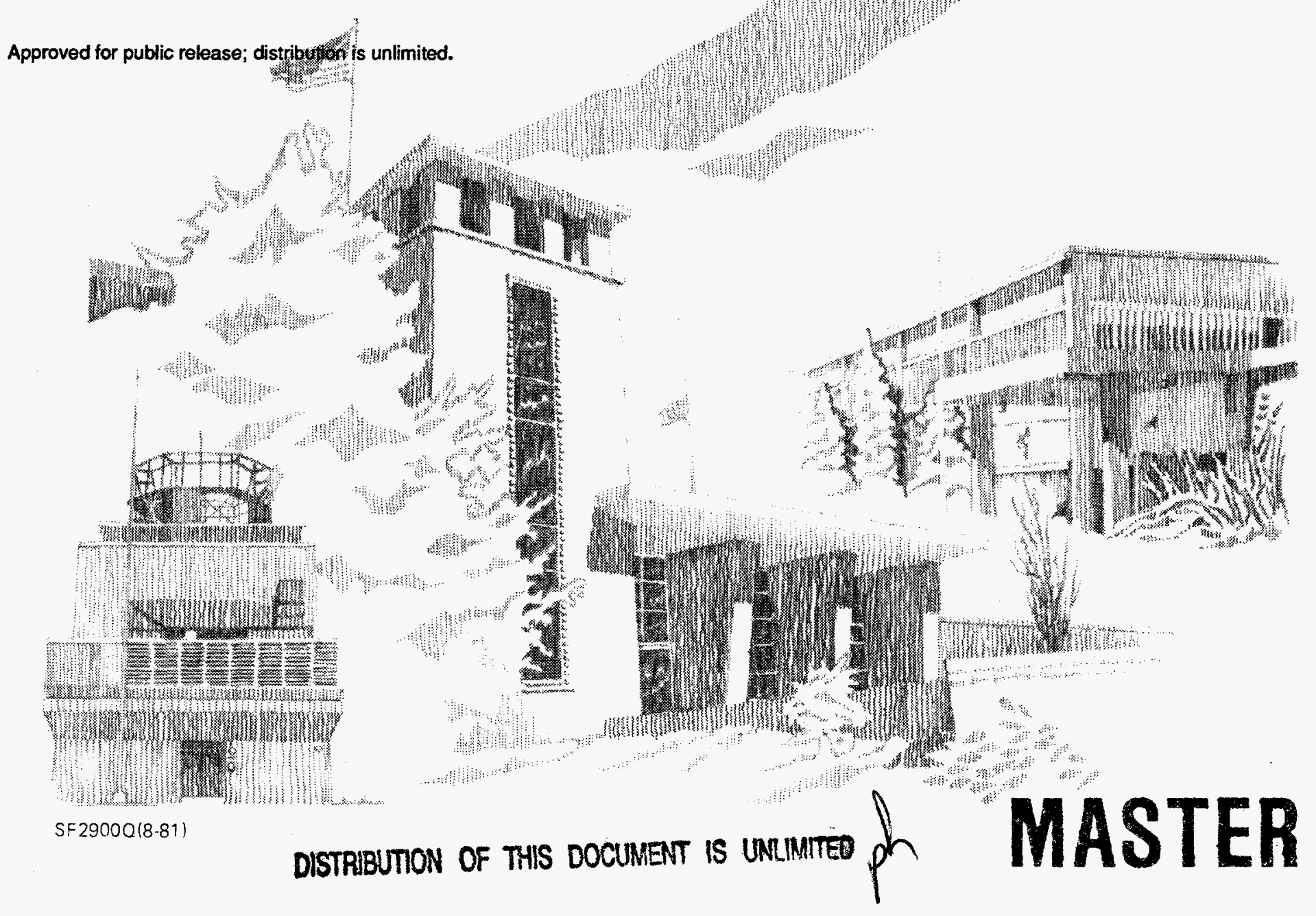


Issued by Sandia National Laboratories, operated for the United States Department of Energy by Sandia Corporation.

NOTICE: This report was prepared as an account of work sponsored by an agency of the United States Government. Neither the United States Government nor any agency thereof, nor any of their employees, nor any of their contractors, subcontractors, or their employees, makes any warranty, express or implied, or assumes any legal liability or responsibility for the accuracy, completeness, or usefulness of any information, apparatus, product, or process disclosed, or represents that its use would not infringe privately owned rights. Reference herein to any specific commercial product, process, or service by trade name, trademark, manufacturer, or otherwise, does not necessarily constitute or imply its endorsement, recommendation, or favoring by the United States Government, any agency thereof or any of their contractors or subcontractors. The views and opinions expressed herein do not necessarily state or reflect those of the United States Government, any agency thereof or any of their contractors.

Printed in the United States of America. This report has been reproduced directly from the best available copy.

Available to DOE and DOE contractors from

Office of Scientific and Technical Information

PO Box 62

Oak Ridge, TN 37831

Prices available from (615) 576-8401, FTS 626-8401

Available to the public from

National Technical Information Service

US Department of Commerce

5285 Port Royal Rd

Springfield, VA 22161

NTIS price codes

Printed copy: A03

Microfiche copy: A01 


$\begin{array}{ll}\text { SAND95 - } 1611 & \text { Distribution } \\ \text { Unlimited Release } & \text { Category UC-902 } \\ \text { Printed April 1996 } & \end{array}$

\title{
Tritium in Surface Soils at the Mixed Waste Landfill, Technical Area 3, Sandia National Laboratories, New Mexico
}

\author{
Jerry L. Peace \\ Environmental Restoration Project \\ Sandia National Laboratories \\ Albuquerque, NM 87185-5800 \\ Tim J. Goering and Michael D. McVey \\ Gram, Inc. \\ 8500 Menaul Blvd. NE, Suite B-370 \\ Albuquerque, NM 87112
}

\begin{abstract}
The Environmental Restoration Project at Sandia National Laboratories, New Mexico is tasked with assessment and remediation of the Mixed Waste Landfill in Technical Area 3. The Mixed Waste Landfill is an inactive, lowlevel radioactive and mixed waste disposal site. The Mixed Waste Landfill was subject to an extensive surface soil sampling program for tritium in July 1993. Results indicate that surface soils at the landfill contain significant levels of tritium. The classified area of the landfill contains the highest levels of tritium. Results also indicate that tritium has migrated beyond the fenced boundary of the classified area of the landfill.
\end{abstract}




\section{Acknowledgements}

The authors wish to acknowledge the excellent technical support provided by Bill Rhodes, Craig Brown, Hans Oldewage, and Gordon Coulter of SNL,NM Department 7714, Radiation Protection Operations, and the logistical support provided by Earl Morse, Wyatt Booher, Erne Ross, and Pat Martinez of IT Corporation. 


\section{Contents}

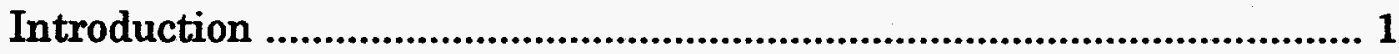

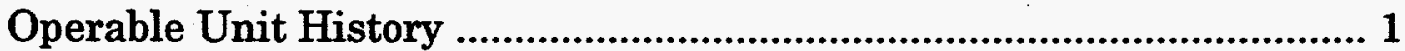

1982 Surface Soil Sampling ....................................................................... 3

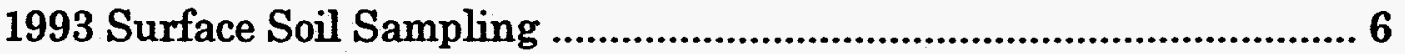

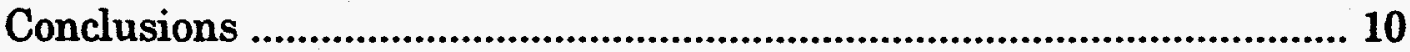

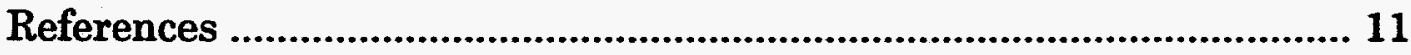

Figures

1 Mixed Waste Landfill ................................................................ 2

2 Mixed Waste Landfill 1982 Tritium Surface Soil Sampling ......... 4

3 Mixed Waste Landfill Tritium in Surface Soils, 1982 .................... 5

4 Mixed Waste Landfill 1993 Tritium Surface Soil Sampling ......... 7

5 Mixed Waste Landfill Tritium in Surface Soils, 1993 .................... 8

6 Mixed Waste Landfill Classified Area Tritium Disposal, 1959 - 1983 


\title{
Tritium in Surface Soils at the Mixed Waste Landfill, Technical Area 3, Sandia National Laboratories, New Mexico
}

\author{
Introduction
}

The Environmental Restoration (ER) Project at Sandia National Laboratories, New Mexico (SNL,NM) is tasked with assessment and remediation of the Mixed Waste Landfill (MWL) in Technical Area 3 (TA 3) under SNL,NM's Resource Conservation and Recovery Act (RCRA) HSWA Part B Operating Permit. The 2.6 acre compound was subject to an extensive surface soil sampling program for tritium in July 1993. A total of 92 surface soil samples were taken in and around the landfill. Sampling locations and density were based on MWL historical records, RCRA field investigation data, and previous SNL,NM environmental monitoring results. Sampling included the southern half of the MWL unclassified area which was not sampled during previous environmental investigations.

\section{Operable Unit History}

The MWL was operated from March 1959 to December 1988 as a disposal site for low-level radioactive and mixed waste. The MWL was opened originally as the "TA 3 low-level radioactive dump" when the existing lowlevel radioactive dump in TA 2 was closed in March 1959. The MWL was the primary disposal site for SNL,NM technical and remote test areas involved in nuclear weapons research and development.

The MWL consists of two distinct disposal areas: the classified area, occupying 0.6 acres, and the unclassified area, occupying 2.0 acres (Figure 1). Wastes in the classified area were disposed of in a series of vertical, cylindrical pits. Historical records indicate that early pits were 3 to 5 feet in diameter and 15 feet deep. Later pits were 10 feet in diameter and 25 feet deep. Once pits were filled with waste, they were backfilled with soil to within 3 feet of the surface then capped with concrete. Wastes in the unclassified area were disposed of in a series of north-south excavated trenches. Records indicate that trenches were 15 to 25 feet wide, 150 to 180 feet long, and 15 to 20 feet deep. Trenches were reportedly backfilled with soil on a quarterly basis and, once filled with waste, capped with originally excavated soils which had been stockpiled at the landfill.

Wastes disposed of in classified pits included depleted, natural, and enriched uranium, thorium, barium, enriched lithium, tritium beds(?), 



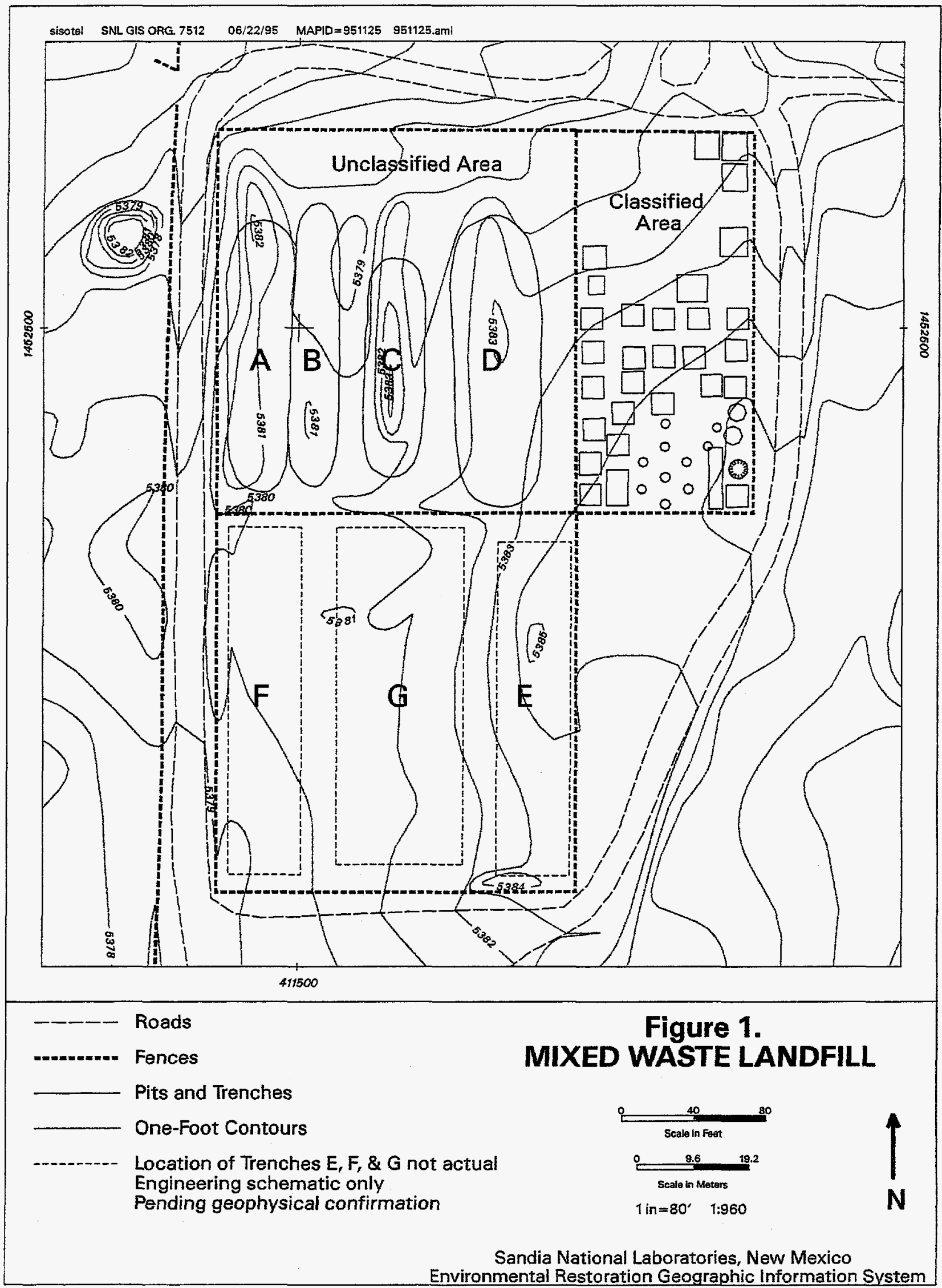


"Intentionally Left Blank" 
liquid scintillation cocktails, neutron generator tubes and targets, plutonium contaminated wastes, and plutonium contaminated weapons test debris from the Nevada test site. Wastes disposed of in unclassified area trenches included construction and demolition materials, contaminated equipment and soils, lead shielding, wood crates, steel drums, lead bricks, cardboard boxes, and dry solids. Wastes disposed of in unclassified area trenches were disposed of at random with no regard to waste source or type.

\section{Surface Soil Sampling}

SNL,NM has maintained an environmental monitoring program since February 1959.1 As part of this program, 100 surface soil samples were collected in June 1982 to determine the extent of tritium distribution and activity in surface soils at the MWL. ${ }^{2}$ Surface soils were sampled to a depth of 2 inches at regular intervals along north-south traverses east of the classified area and west of the unclassified area; along north-south traverses inside the northern half of the unclassified area; along east-west traverses inside the classified area, and immediately adjacent to pit 33, the currently used classified disposal pit. Figure 2 depicts the MWL as it existed in 1982 and the areas of tritium surface soil sampling.

1982 sampling results are presented in Figure 3. Tritium activities are greatest within the classified area of the landfill. Tritium activities range from $10,336 \mathrm{pCi} / \mathrm{g}$ to $4,295 \mathrm{pCi} / \mathrm{g}$ around active pit 33 . Tritium occurs in the unclassified area in soils around Trench $\mathrm{C}$, the most recently active disposal trench, and Trench D. In 1967, approximately 270,000 gallons of coolant wastewater from the Sandia Engineering Reactor in TA 5 were disposed of in Trench D. The trench already contained miscellaneous wastes at the time. Approximately $1 \mathrm{Ci}$ of total radioactivity, mainly short-lived radionuclides, was discharged into the open trench with the cooling water.

The 1982 sampling data clearly indicate that tritium has migrated beyond the fenced boundary of the classified area. Tritium activities east of the classified area range from $7.84 \mathrm{pCi} / \mathrm{g}$ to $1.41 \mathrm{pCi} / \mathrm{g}$. Migration is probably due to diffusion through the vadose zone due to a high concentration gradient in and around disposal pit 33. Sampling was not conducted in the southern half of the unclassified area in 1982 since this area was only recently opened for waste disposal. 


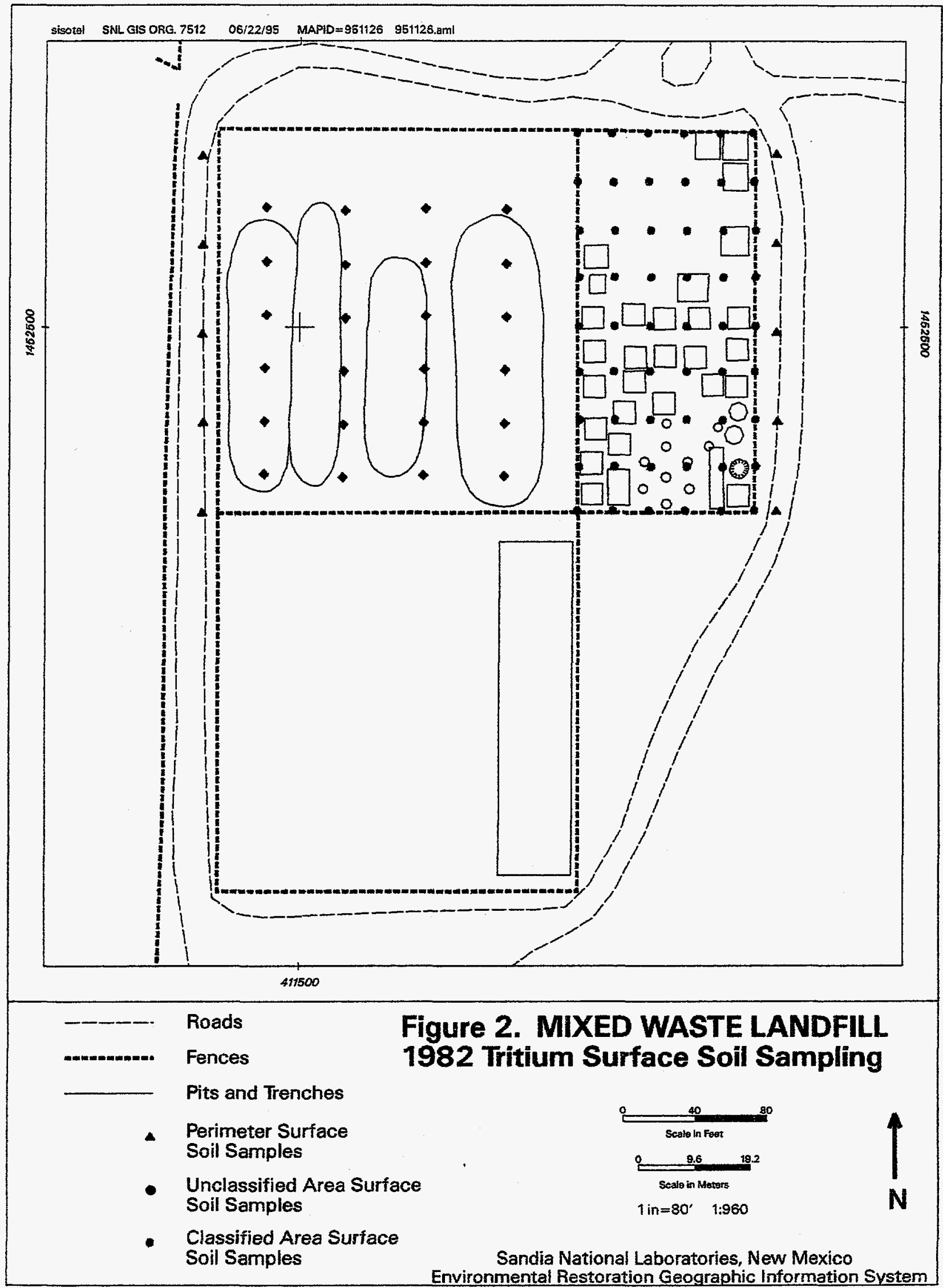


"Intentionally Left Blank" 


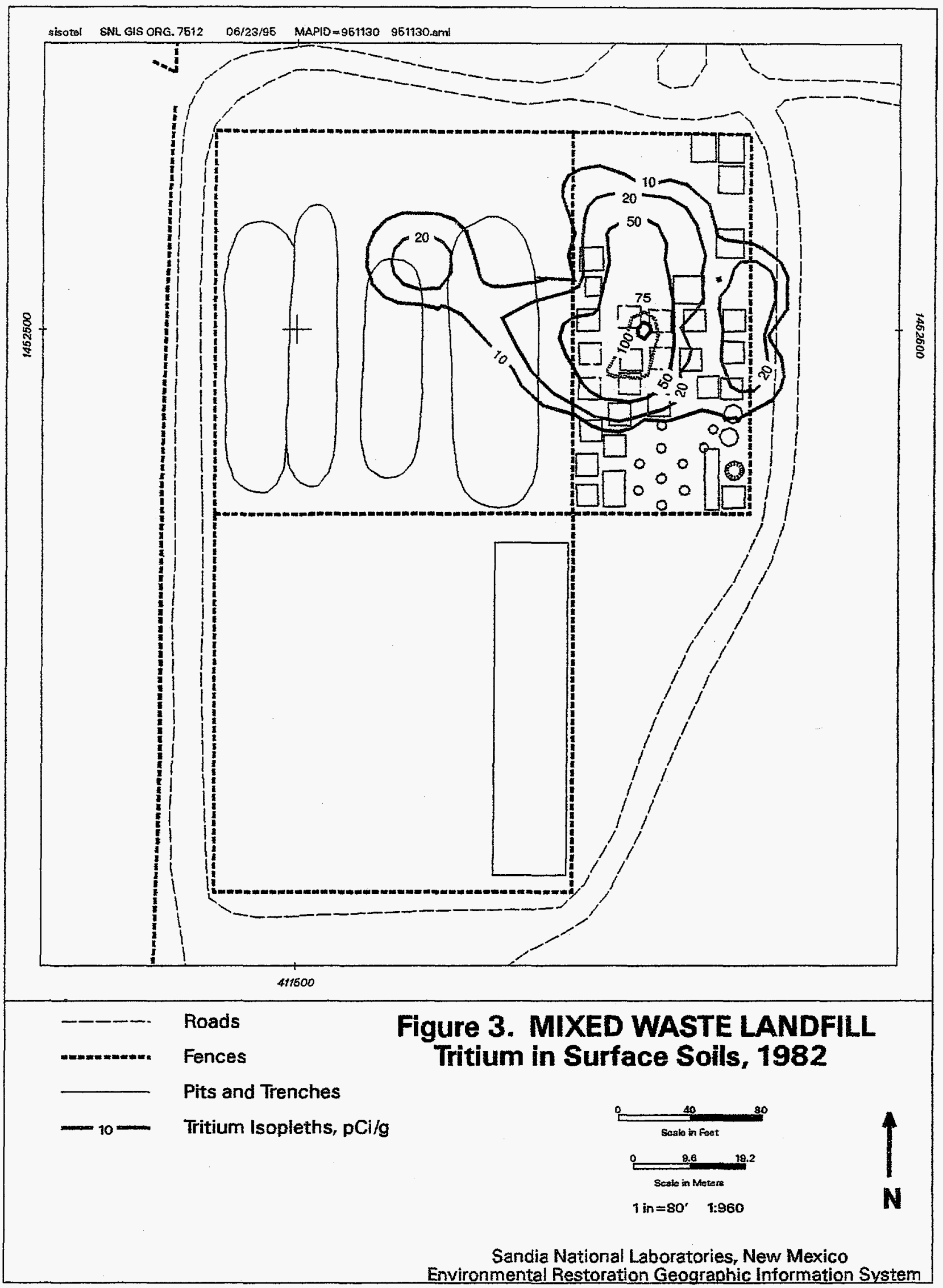


"Intentionally Left Blank" 


\section{Surface Soil Sampling}

The 1993 surface soil sampling program was conducted for three reasons. 1) To continue SNL,NM's environmental monitoring program in order to detect the release and/or migration of radioactive material from the MWL; 2) To augment surface soil sampling for tritium conducted at the MWL in June 1982; and 3) To fulfill assessment requirements outlined in the MWL RCRA facility investigation work plan.

In July 1993, 92 surface soil samples were collected at the MWL as part of MWL RCRA facility investigation assessment activities (Figure 4). Sampling locations and density were based on MWL historical records, RCRA facility investigation field data, and 1982 sampling results. Sampling was expanded to include the southern half of the unclassified area which was not sampled in 1982. The southern half of the unclassified area of the landfill was permanently closed to waste disposal operations in December 1988.

1993 sampling results are presented in Figure 5 . These data closely resemble 1982 results. Tritium activities, once again, are greatest within the classified area of the landfill and seem to form concentric rings around pit 33 . The maximum tritium activity obtained during the 1993 program, 1103 $\mathrm{pCi} / \mathrm{g}$, was obtained at the southern edge of inactive pit 33 .

Historical records indicate that a total of $1,861 \mathrm{Ci}$ of tritium were disposed of at the MWL from March 1959 to January 1983. 1,451 Ci were disposed of in the classified area of the landfill. $822 \mathrm{Ci}$ of the amount disposed of in the classified area were disposed of in pit 33 alone between May 1979 and January 1983. The remaining $410 \mathrm{Ci}$ of the tritium disposed of at the MWL were probably disposed of in unclassified area Trenches A through $D$. Trench $A$, the first active trench, was excavated in late 1962 and Trench $C$, the last active trench, was backfilled and capped in early 1980. Figure 6 depicts the amount of tritium disposed of in specific pits in the classified area of the landfill from 1959 to 1983 . No information has been found to date as to what amount of tritium was disposed of in Trenches A through D. 


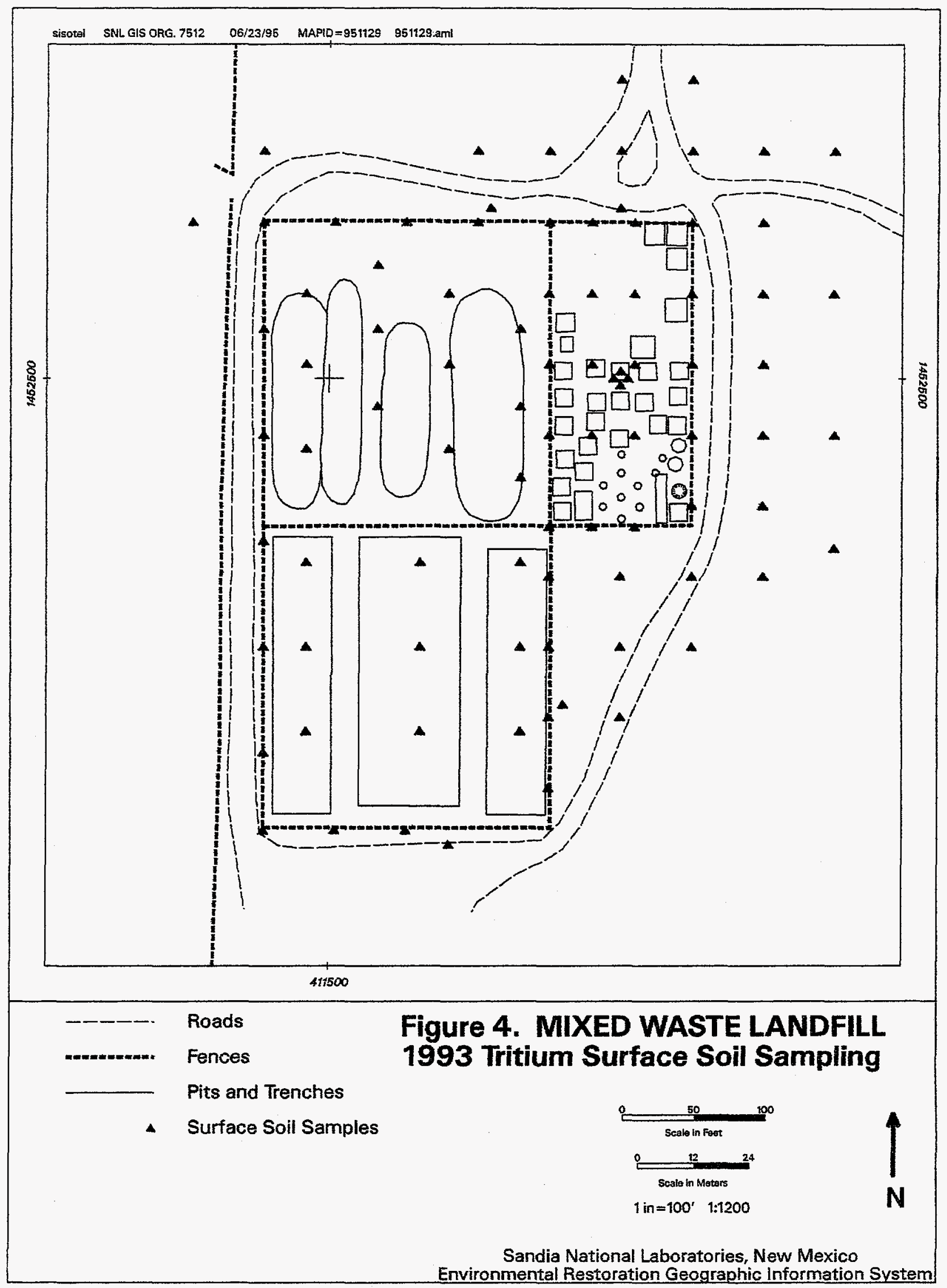


"Intentionally Left Blank" 


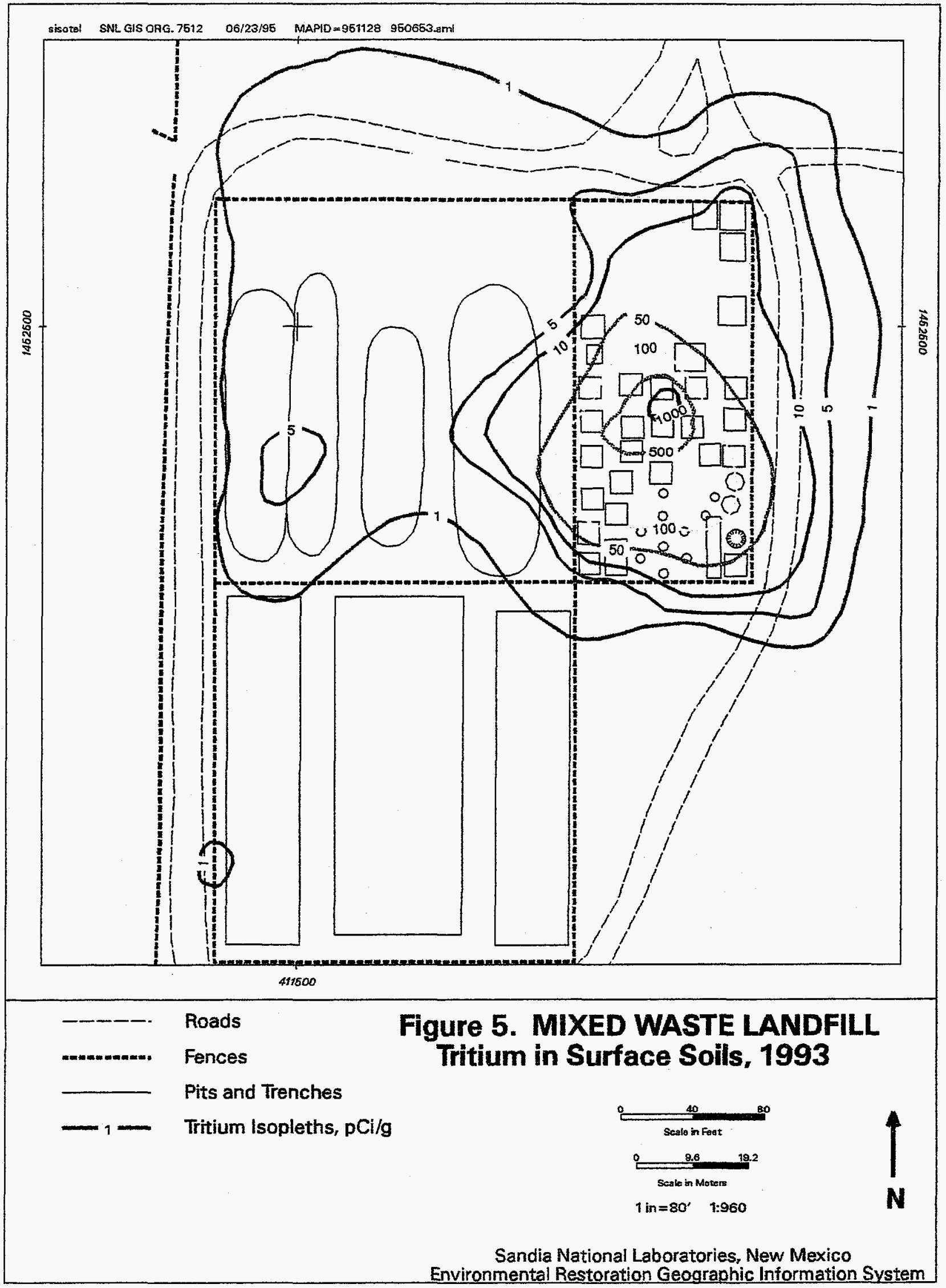


"Intentionally Left Blank" 


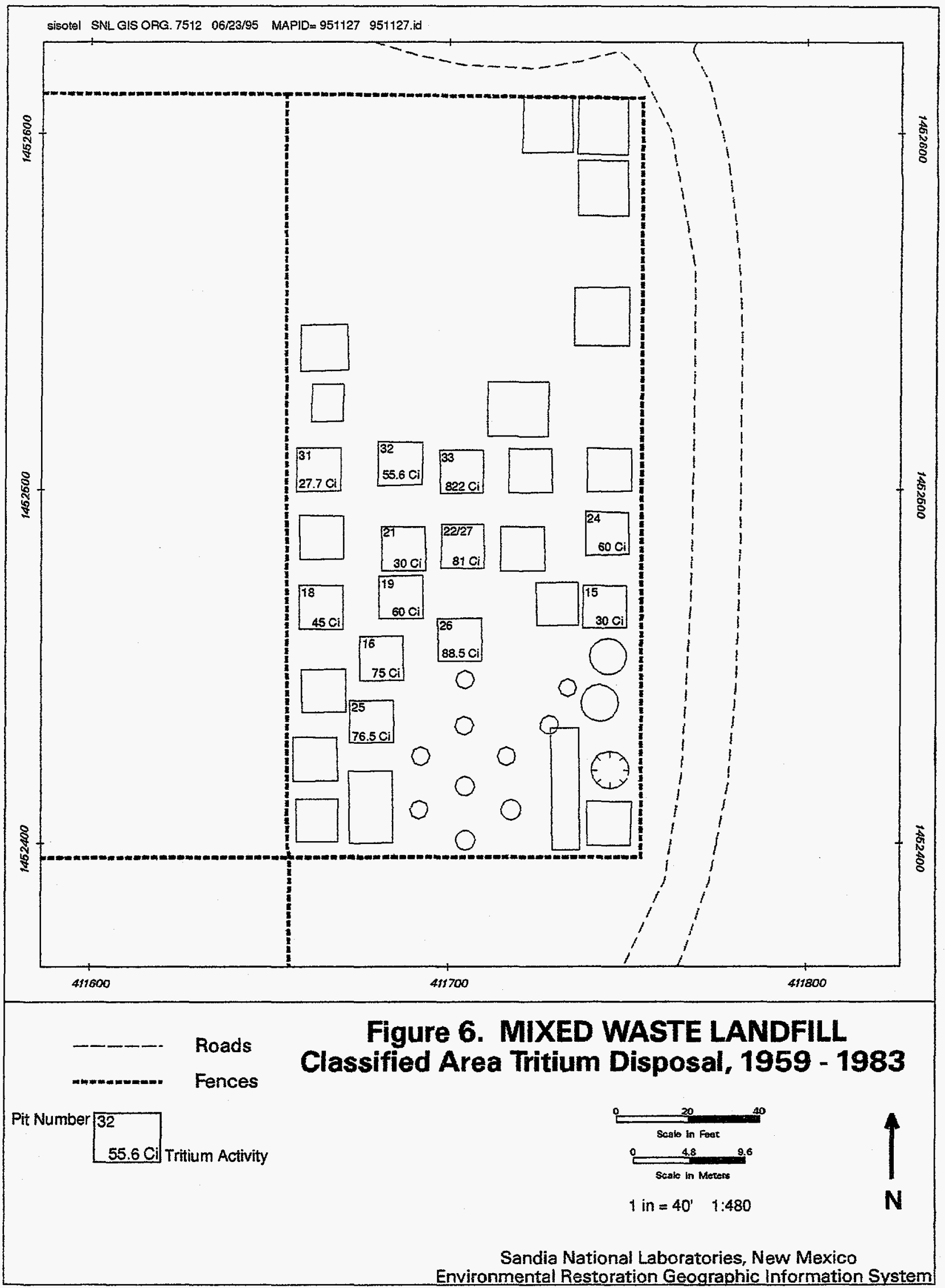


"Intentionally Left Blank" 


\section{Conclusion}

The distribution of tritium in surface soils in and around the MWL is easily attributed to tritium disposal practices and history at the MWL. $78 \%$ of the total tritium disposed of at the MWL was disposed of in the classified area. $57 \%$ of the total tritium disposed of in the classified area was disposed of in pit 33. 1982 and 1993 tritium activity and distribution in surface soils clearly substantiate MWL disposal records. Tritium distribution is restricted primarily to the northern half of the MWL (Figure 5). The greatest concentration of tritium occurs in the classified area with activity levels forming concentric rings around inactive pit 33.

1993 tritium activities are one order of magnitude less than 1982 tritium activities. This is probably due to a combination of 3 natural mechanisms: 1) radioactive decay of the tritium;2) evapo-transpiration of the tritium; and 3) diffusion of the tritium into the vadose zone. 



\section{References}

1. L. W. Brewer, Environmental Monitoring Report for Sandia Laboratories from 1964 to 1972, Sandia National laboratories, SLA-73-0339, March 1973.

2. G. C. Millard, C. E. Gray, T. N. Simmons, and B. L. O'Neal, 1982 Environmental Monitoring report, Sandia National laboratories, Albuquerque, New Mexico, SAND83-0789, April 1983. 
DISTRIBUTION:

1 MS 1309 Environmental Operations Records Center, 7512

1 MS 1311 H. S. Hwang, 7575

1 MS 1311 T. A. Culp, 7575

$1 \quad$ MS 1147 W. B. Cox, 7581

1 MS 1148 R. E. Fate, 7585

1 MS 1148 J. L. Peace, 7585

1 MS 1148

1 MS 1148

2 MS 0100

T. G. Goering, 7585

M. D. McVey, 7585

Document Processing, 7613-2

For DOE/OSTI

1 MS 1093 W. G. Rhodes, 7713

1 MS $1093 \quad$ H. D. Oldewage, 7714-3

1 MS 9018 Central Technical Files, 8523-2

1 MS 0619 Print Media, 12615

5 MS 0899 Technical Library, 13414 